\title{
Air quality in enclosed railway stations
}

1 John E. Thornes PhD, FRMetS, FRGS

Emeritus Professor of Applied Meteorology, School of Geography, Earth and Environmental Sciences, University of Birmingham, Birmingham, UK (corresponding author: j.e.thornes@bham.ac.uk)

2. Alice Hickman BSC

Graduate student, Birmingham Centre for Railway Research and Education, School of Civil Engineering, University of Birmingham Birmingham, UK

3 Chris Baker PhD, CEng, FICE, FIHT, FHEA, FRMetS

Professor of Environmental Fluid Mechanics, Birmingham Centre for Railway Research and Education, School of Civil Engineering, University of Birmingham, Birmingham, UK
4 Xiaoming Cai PhD

Senior Lecturer, School of Geography, Earth and Environmental Sciences, University of Birmingham, Birmingham, UK

5 Juana Maria Delgado Saborit PhD

Lecturer, School of Geography, Earth and Environmental Sciences, University of Birmingham, Birmingham, UK
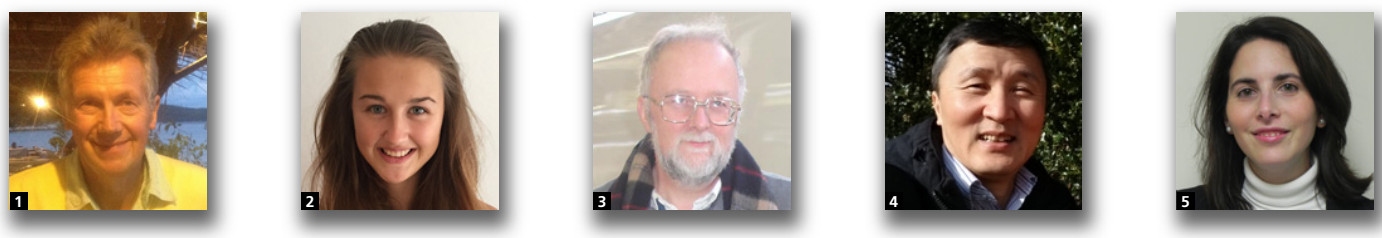

In 2012, the World Health Organization's International Agency for Research on Cancer (IARC) reclassified diesel engine exhaust and related ambient air pollution to be carcinogenic and associated with increased mortality from lung cancer. This could have critical consequences for both public and occupational health in enclosed railway stations where ventilation is often inadequate. Recent policies encouraging a shift to public transport, along with increasing passenger and train numbers, have led to a variety of co-benefits, including improved health and well-being from increased walking and cycling. This paper considers the unintended consequences of a reduction of air quality in crowded enclosed railway stations and concludes with a number of possible interventions to ensure that public health is not affected, especially by air pollution from stationary diesel trains. Pollution from electric trains can also lead to poor air quality due to the production of metal-rich ultrafine particles from brake linings, friction between wheel and rail, and from overhead pantographs. Current occupational health standards are not suitable for enclosed railway stations and need to be reconsidered in the light of the IARC findings. More measurements of the levels of particulates and nitrogen dioxide in enclosed railway stations need to be undertaken and published.

\section{Introduction}

At a time when the general public is being encouraged to get out of their cars and walk, cycle and/or use public transport, it is important to assess not just the health co-benefits but also any unintended consequences. Enclosed railway stations such as Birmingham New Street, Marylebone, Paddington and Waverley, which have a significant number of diesel trains, are most at risk. Effectively, these stations are indoor environments that require substantial artificial ventilation to diffuse and dispose of the air pollution generated by both diesel and electric trains.

Road and rail traffic are key contributors to poor air quality in the UK. A report by the Committee on the Medical Effects of Air Pollutants (COMEAP) suggests that the average life expectancy in the UK is 6 months lower due to exposure to particulate air pollution produced by human activities, with an estimated annual cost to society of up to $£ 16$ billion (COMEAP, 2010). Urban transport strategies (mostly aiming to reduce greenhouse gas emissions) can deliver several health co-benefits. For example, strategies that encourage walking and cycling have the added benefit of reducing air pollution and increasing physical activity, thus tackling one of the most pressing and challenging public health problems of the day. However, only one-third of Europeans currently reach the recommended levels of physical activity.

Since privatisation of the railways in the UK, passenger numbers have dramatically increased. As reported by the Office of Rail and Road (ORR), more than 1653 million passenger journeys were made in 2014-2015 compared with 1586 million in 2013-2014, a 4.2\% increase (ORR, 2015). 
This growth is greater than in other European countries, with passenger numbers doubling in the UK since 1997-1998, compared with increases of $37 \%$ in France, $21 \%$ in Germany and $18 \%$ in the Netherlands (RDG, 2015). Network Rail is planning to invest $£ 35$ billion over the next 5 years, a third of which will be spent on improving stations, electrification and new track, a third on track renewals and a third on running the railways. The train operating companies need to reduce the average age of the current rolling stock from almost 20 years old according to the Rail Delivery Group (RDG, 2015). However, despite the increase in the numbers of trains and passengers, there has been no research to monitor the impact on air quality and occupational and/or public health in railway stations in the UK.

A recent survey by the Environmental Systems Research Institute (Greener Business, 2008) found that Birmingham is the worst city in Britain for commuting times, with workers spending on average more than $1 \mathrm{~h}$ per day $(61.2 \mathrm{~min})$ travelling to and from work due to the complex network of roads and motorways and the crowded rail network. Edinburgh came in second (55.3 $\mathrm{min})$, London third (52.4 min) and Oxford fourth $(51.5 \mathrm{~min})$. There is a need to assess the impact on public health across cities with long commuting times - and to examine the key sources of air pollution associated with these commutes.

The responsibility for monitoring air quality in railway stations rests with local authority environmental health departments in conjunction with Network Rail or the delegated train operating company. The Railways Safety and Standards Board (RSSB) has just launched a new occupational health and wellbeing initiative (RSSB, 2014) and was involved in a workshop on railway station air quality organised by Public Health England, held at King's College, London in September 2014. If occupational or public health air quality guidelines are shown to be exceeded, it is imperative that the relevant stakeholders are immediately made aware and take appropriate measures to monitor and improve air quality.

Currently, no data on station air quality are made available to the public and this issue must be addressed. Network Rail has suggested that the electrification of lines will improve the environment (NR, 2015), stating

Electric trains cause 20-35 per cent lower carbon emissions than diesels with no emissions at the point of use, improving air quality in pollution hot spots such as city centres. They are also quieter, improving quality of life for people living near the railway.

This implies that carbon dioxide $\left(\mathrm{CO}_{2}\right)$ is the main problem and disregards the increased ultrafine particulate pollution that electric trains produce from brake linings, friction and overhead cables (Abbasi et al., 2013; Loxham et al., 2013; Martins et al., 2016; Salma, 2009). Ultrafine particles, which are unregulated in the UK, are often metal rich and thus potentially more likely to cause health problems (such as cancer and emphysema) in workers and passengers than the larger, regulated dust particles $\left(\mathrm{PM}_{10}\right.$ and $\left.\mathrm{PM}_{2 \cdot 5}\right)$ (Loxham et al., 2013).

In the UK, around $60 \%$ of journeys presently take place on electric trains and $40 \%$ on diesel trains (DoT, 2009). According to Frank Kelly, professor of environmental health at King's College, London, 'diesel engines in buses, vans, cars and trains may be responsible for thousands of premature deaths a year and cost the NHS [National Health Service] billions of pounds' (Vidal, 2014).

The serious health impacts of diesel exhaust pollution and other transport pollutants are at the forefront of the current European air pollution research agenda. The official death toll for air pollution in the UK is currently 29000 , but this does not take into account levels of nitrogen dioxide $\left(\mathrm{NO}_{2}\right)$, which is mainly emitted by diesel engines.

Diesel cars have become increasingly popular in recent years as they discharge 15\% less carbon dioxide (Hope, 2015). The number of diesel cars in the UK has risen from 1.6 million to 11 million and now accounts for a third of the nation's vehicles (Swinford, 2015). In 2010, COMEAP highlighted the health issues surrounding diesel emissions and, 5 years on, the government is yet to act (COMEAP, 2010; Hope, 2015). Carslaw et al. (2011) reported that the concentration of oxides of nitrogen $\left(\mathrm{NO}_{\mathrm{x}}\right)$ showed a clear declining trend prior to 2004, but between 2004 and 2009 the trend turned less positive. This may be the result of the increasing number of diesel cars on the roads. Additionally, particulate filters on diesel cars are not as effective in the real world as they are in testing laboratories, as highlighted by newly uncovered illegal emissions-rigging software used by some car manufacturers. The Mayor of Paris has promised to ban diesel cars from the city centre by 2020 . Finding alternatives to diesel vehicles (cars and trains) should be a priority in the UK as well. According to Hertel and Goodsite (2009: p. 9)

Previously, the fraction of NOx directly emitted as $\mathrm{NO}_{2}$ was only about 5 to $10 \%$ in countries with a small fraction of diesel engines. Due to the use of catalytic convertors and an increasing number of diesel engines with high fraction of $\mathrm{NO}_{2}$ in the exhaust, this value may in some regions be as high as $40 \%$.

It is vital for the health and well-being of passengers that may switch from commuting by car to using public transport that the air quality encountered in enclosed railway stations should pose no risk to public health. It is also important that the health of staff working at enclosed railway stations should be monitored and protected.

\section{Air pollutants in railway stations}

Air pollutants in railway stations come from both diesel engine exhaust emissions (DEEEs) and electric train emissions, 


\begin{tabular}{|c|c|}
\hline DEEE & Health effect \\
\hline Oxides of nitrogen & $\begin{array}{l}\text { Symptoms of bronchitis in asthmatic children increases in association with long-term } \\
\text { exposure; reduced lung function growth is currently being observed in cities of Europe } \\
\text { and North America (WHO, 2015) }\end{array}$ \\
\hline Particulate matter & $\begin{array}{l}\text { Fine particles can penetrate deep into lungs triggering inflammation and aggravation of } \\
\text { heart and lung dieses (Defra, 2013) }\end{array}$ \\
\hline Carbon dioxide & $\begin{array}{l}\text { Carbon dioxide can cause headaches, dizziness, confusion and loss of consciousness when } \\
\text { in higher concentrations (Harper, 2011) }\end{array}$ \\
\hline Carbon monoxide & $\begin{array}{l}\text { Prevention of oxygen uptake by the blood leading to a reduction in oxygen supplied to the } \\
\text { heart, particularly in those suffering from heart disease (Defra, 2013) }\end{array}$ \\
\hline Oxides of sulfur & $\begin{array}{l}\text { Affects the respiratory system, function of the lungs and causes irritation of the eyes. When } \\
\text { inhaled, pollutants can cause inflammation of the respiratory tract resulting in coughing, } \\
\text { aggravation of asthma and chronic bronchitis (WHO, 2015) }\end{array}$ \\
\hline $\begin{array}{l}\text { Polycyclic aromatic hydrocarbons } \\
\text { (PAHs) }\end{array}$ & $\begin{array}{l}\text { Short-term exposure can lead to impaired lung function in asthmatics, thrombotic effects in } \\
\text { coronary heart disease sufferers, eye irritation, nausea, vomiting and diarrhoea. Long-term } \\
\text { exposure can result in cancerous illness, kidney and liver damage and cell damage } \\
\text { (Kim et al., 2013) }\end{array}$ \\
\hline $\begin{array}{l}\text { Benzene, toluene, ethylbenzene } \\
\text { and xylene (BTEX) volatile } \\
\text { organic compounds }\end{array}$ & $\begin{array}{l}\text { Both carcinogenic and non-carcinogenic risks, including cancerous illnesses, respiratory } \\
\text { irritation and central nervous system damage (Durmusoglu et al., 2010) }\end{array}$ \\
\hline
\end{tabular}

Table 1. The associated health effects from exposure to diesel

engine exhaust emissions (DEEEs)

of which diesel emissions are more polluting and hazardous (AEA Technology, 2001). Diesel engines release a variety of pollutants that have a range of effects on human health and the length of exposure can significantly influence these effects. Those who are younger, in a fit state of health and exposed to moderate air pollution are less likely to experience any shortterm effects; however, elevated levels or long-term exposure could lead to the development of much more serious conditions such as respiratory illness, heart disease or cancer. Each of the DEEEs has a damaging effect on health (Table 1). Therefore it is of upmost importance to abide by the limits in place to help prevent the health deterioration of both employees and the public.

\section{Air quality guidelines for public health}

The air quality objectives specifically for use by local authorities in carrying out their air quality management duties are set out in the Air Quality (England) Regulations 2000 (HMG, 2000) and the Air Quality (England) (Amendment) Regulations 2002 (HMG, 2002a). Reference is also made to the Air Quality Standards Regulations 2010 (HMG, 2010), which came into force in June 2010, and implement relevant parts of European Union (EU) directive 2008/50/EC (EC, 2008) on ambient air quality. The Environment Act 1995 (1995) requires that the UK government produces a national 'air quality strategy' containing standards, objectives and measures for improving ambient air quality and to keep these policies under review. The current air quality strategy was made in 2007 under section 80 of the Environment Act 1995. On the basis of the above, numerical environmental quality standards relevant to the assessment are summarised and referred to as air quality limit values (Table 2).

The health impacts of nitrogen dioxide and particulates are constantly under review (Mills et al., 2015), and the House of Commons Environmental Audit Committee report Action on Air Quality (HCEAC, 2014) published in December 2014 summarises recent significant findings, including the following.

- The recent review of evidence on the health aspects of air pollution, undertaken by the World Health Organization (IARC, 2012; WHO, 2013) at the request of the European Commission (EC), is to inform revision of the EU's air quality policies. This review confirmed evidence linking exposure to ambient air pollution with adverse effects on the respiratory and cardiovascular systems and suggested a possible association with the endocrine system (diabetes) and the nervous system. It also suggested that ambient nitrogen dioxide has a direct effect on respiratory outcomes.

- There are significant health effects below the limit values, and so not attaining the limit values should be seen in a very negative light.

- In April 2014, Public Health England calculated the local impact of particulate matter on premature mortality, ranging from $2 \cdot 5 \%$ in some local authorities in rural Scotland and Northern Ireland to over $8 \%$ in some London boroughs (6.4\% in Birmingham). 


\begin{tabular}{|c|c|c|c|c|}
\hline \multirow[t]{2}{*}{ Pollutant } & \multicolumn{2}{|c|}{ Workplace exposure limits } & \multicolumn{2}{|c|}{ EU air quality standards } \\
\hline & $8 \mathrm{~h}$ (TWA) & $15 \min (T W A)$ & 1 year & Short term \\
\hline Nitrogen dioxide & $\mathrm{n} / \mathrm{a}$ & $\mathrm{n} / \mathrm{a}$ & $40 \mu \mathrm{g} / \mathrm{m}^{3}$ & $200 \mu \mathrm{g} / \mathrm{m}^{3}$ ( $1 \mathrm{~h}$, not to be exceeded more than 18 times annually) \\
\hline $\mathrm{PM}_{10}$ & $\mathrm{n} / \mathrm{a}$ & $\mathrm{n} / \mathrm{a}$ & $40 \mu \mathrm{g} / \mathrm{m}^{3}$ & $50 \mu \mathrm{g} / \mathrm{m}^{3}$ ( $24 \mathrm{~h}$, not to be exceeded more than 35 times annually) \\
\hline $\mathrm{PM}_{2 \cdot 5}$ & $\mathrm{n} / \mathrm{a}$ & $\mathrm{n} / \mathrm{a}$ & $25 \mu \mathrm{g} / \mathrm{m}^{3}$ & $\mathrm{n} / \mathrm{a}$ \\
\hline Carbon dioxide & $9150 \mathrm{mg} / \mathrm{m}^{3}$ & $27400 \mathrm{mg} / \mathrm{m}^{3}$ & $\mathrm{n} / \mathrm{a}$ & $\mathrm{n} / \mathrm{a}$ \\
\hline Carbon monoxide & $35 \mathrm{mg} / \mathrm{m}^{3}$ & $232 \mathrm{mg} / \mathrm{m}^{3}$ & $\mathrm{n} / \mathrm{a}$ & $10 \mu \mathrm{g} / \mathrm{m}^{3}$ (Maximum daily $8 \mathrm{~h}$ mean) \\
\hline Oxides of sulfur & $\mathrm{n} / \mathrm{a}$ & $\mathrm{n} / \mathrm{a}$ & $\mathrm{n} / \mathrm{a}$ & $\begin{array}{l}350 \mu \mathrm{g} / \mathrm{m}^{3} \text { ( } 1 \mathrm{~h} \text {, not to be exceeded more than } 24 \text { times annually) } \\
125 \mu \mathrm{g} / \mathrm{m}^{3} \text { ( } 24 \mathrm{~h} \text {, not to be exceeded more than } 3 \text { times annually) }\end{array}$ \\
\hline PAHs & $\mathrm{n} / \mathrm{a}$ & $\mathrm{n} / \mathrm{a}$ & $1 \mathrm{ng} / \mathrm{m}^{3}$ & $\mathrm{n} / \mathrm{a}$ \\
\hline Benzene & $3.25 \mathrm{mg} / \mathrm{m}^{3}$ & $\mathrm{n} / \mathrm{a}$ & $5 \mu \mathrm{g} / \mathrm{m}^{3}$ & $\mathrm{n} / \mathrm{a}$ \\
\hline
\end{tabular}

Table 2. Workplace exposure limits (HSE, 2013) and EU air quality standards (EC, 2012a, 2012b) for pollutants present at train stations due to diesel emissions

The significant health risks that nitrogen dioxide poses have been understood for many years. Hence, in the EU 'First Daughter directive' (1999/30/EC; EC, 1999), limits were set for nitrogen dioxide. The directive limits nitrogen dioxide concentrations in order to protect health; nitrogen dioxide is limited to $40 \mu \mathrm{g} / \mathrm{m}^{3}$ annually and an hourly limit of $200 \mu \mathrm{g} / \mathrm{m}^{3}$, which must not be exceeded more than 18 times per calendar year (AQEG, 2004). These limits came into force on 1 January 2010, giving the UK 10 years to achieve this target. With such ambitious targets, the EU air quality directive (2008/50/EC; EC, 2008), which came into effect in June 2008, stated that member states had the opportunity to apply for a 5-year extension for meeting the nitrogen dioxide limits (EC, 2012a, 2012b). Yet, despite not being on track on achieve the new EU law, the UK failed to apply for an extension. This has led to the UK breaching EU law since 2010, with 16 different cities and regions exceeding the limit values (EC, 2014). The UK Department for Environment, Food and Rural Affairs (Defra) states that average roadside concentrations of nitrogen dioxide have fallen by $15 \%$ since 2010 while nitrogen dioxide emissions and background concentrations have halved over the last two decades (Rincon, 2015). Despite all this, major cities such as Birmingham, Leeds and London are not set to achieve the EU limits until 2030 (Defra, 2014). Measurements show that the primary cause of exceeding the nitrogen dioxide limit values is vehicle emissions within cities and urban areas.

In order to comply with the nitrogen dioxide limit of $40 \mu \mathrm{g} / \mathrm{m}^{3}$ annually, air quality plans were published in September 2011 (Defra, 2011) and December 2015 (Defra, 2015). For example, the West Midlands plan illustrates how the implementation of a low-emission zone (LEZ) will affect nitrogen dioxide concentrations. The LEZ scenario would require all heavy goods vehicles (HGVs) and buses to meet the Euro VI emission standards (EC, 2009) for both oxides of nitrogen and $\mathrm{PM}_{10}$ by 2020 . If this could be achieved, the nitrogen dioxide emissions for the area are projected to comply with the EU limits by 2020 (Defra, 2015). Although air quality plans were created in September 2011, with aim of reducing emissions across the country, the UK is still failing to conform to EU law. Therefore, as a result of a unanimous ruling, the EU ordered the UK government to prepare new air quality plans, which were submitted to the EC in December 2015 (Rincon, 2015).

\section{Air quality guidelines for occupational health}

Workers are often exposed to harmful substances in the workplace, such as chemicals, dust and fumes, which could have a significant impact upon their health and workplace exposure limits (WELs) have been set to protect the health of employees in Britain (HSE, 2013). The EH40/2005 WELs are referred to as time-weighted averages (TWA) for both long-term $(8 \mathrm{~h})$ and short-term (15 $\mathrm{min})$ exposure. In reference to the rail network, employees are exposed to emissions from diesel engines but, surprisingly, there is no WEL for nitrogen dioxide or oxides of sulfur or particulate matter (PM). The regulated WEL for carbon monoxide (CO) is much higher than the limits set for public health (Table 2). The probable reason for the higher occupational limit is that those working among potentially harmful substances are considered to be fitter and healthier than the more vulnerable general public. Although there are no limits for polycyclic aromatic hydrocarbons (PAHs), they are one of the substances that are biologically monitored and a guidance value has been set by the Health and Safety Executive (HSE) (HSE, 2013).

\section{Air quality data for railway stations}

There is very little published data on air quality at open or enclosed railway stations. The time spent by passengers waiting for trains will vary considerably, from several minutes to up to an hour or so for delayed trains. Regular commuters will 
encounter any air pollution twice per day and up to $250 \mathrm{~d}$ per year. Thus, both short-term (acute, e.g. asthma) and long-term (chronic, e.g. bronchitis) health problems may occur.

\subsection{A Dutch airport station (30 million passenger entries/exits)}

A Dutch airport station is in the middle of a $5.1 \mathrm{~km}$ long tunnel and is used by $60000-150000$ people each day. There are three platform islands about $400 \mathrm{~m}$ long and 25-30 trains per hour pass through during the day, all of which are electrically powered by overhead catenary. All the platforms are cleaned daily using electrically powered ride-on machines. There is no active ventilation other than the 'piston action' of the trains. Loxham et al. (2013) reported that metal-rich (iron) particle pollution from ultrafine dust $\left(\mathrm{PM}_{0 \cdot 1}\right)$, generated by braking and wheel friction and friction with the overhead catenaries, was likely to cause more health problems than larger particles. These tiny dust particles have the potential to penetrate deep into the lungs - right into the alveoli. Over three sampling days in the underground platform tunnels beneath the airport, Loxham et al. found 'coarse' $\mathrm{PM}_{10}$ at concentrations of $169 \mu \mathrm{g} / \mathrm{m}^{3}$, 'fine' $\mathrm{PM}_{2.5}$ at $75.3 \mu \mathrm{g} / \mathrm{m}^{3}$ and 'ultrafine' $\mathrm{PM}_{0 \cdot 1}$ at $37 \cdot 7 \mu \mathrm{g} / \mathrm{m}^{3}$. The underground particulate matter was found to be rich in iron, accounting for more than $40 \%$ by mass, and several other transition metals (copper, chromium, manganese and zinc).

\subsection{Paddington station, London (35 million passenger entries/exits)}

Paddington station is an enclosed historic railway station with $70 \%$ of trains powered by diesel. The enclosed canopy space is about $15 \mathrm{~m}$ high, $100 \mathrm{~m}$ wide and $250 \mathrm{~m}$ long. Chong et al. (2015) carried out a $5 \mathrm{~d}$ survey (17-21 September 2012) of air quality and found that nitrogen dioxide levels were significantly higher than in nearby streets and regularly broke EU thresholds. They compared the data with the nearby Marylebone roadside air quality site (1.5 km away), which has the reputation of being one of the worst sites in London for air quality. The comparisons indicated that air quality at the train station was more polluted than the nearby roadside: both $\mathrm{PM}_{2.5}$ and nitrogen dioxide within Paddington station were shown to be statistically higher than Marylebone on three out of the five sampling days and measured sulfur dioxide $\left(\mathrm{SO}_{2}\right)$ within Paddington station was statistically higher than Marylebone on all days of measurements. Hourly mean $\mathrm{PM}_{2 \cdot 5}$ mass concentrations averaged $16 \mu \mathrm{g} / \mathrm{m}^{3}$ (range 2-68 $\mu \mathrm{g} / \mathrm{m}^{3}$ ) and hourly mean nitrogen dioxide concentrations averaged $140 \mu \mathrm{g} / \mathrm{m}^{3}$ (range $94-229 \mu \mathrm{g} / \mathrm{m}^{3}$ ).

\subsection{Waverley station, Edinburgh (19 million passenger entries/exits)}

Waverley station is an enclosed railway station with more than 20 platforms in operation over the years. A recent study (Gardner, 2012) found nitrogen dioxide levels up to seven times higher than the EU public health thresholds. Using diffusion tubes exposed for 3 weeks at various locations around the station, concentrations were found to be in the range $200-300 \mu \mathrm{g} / \mathrm{m}^{3}$ whereas nearby street levels (Princes Street, Cowgate and South Clerk Street) were in the broad range of $30-80 \mu \mathrm{g} / \mathrm{m}^{3}$; the annual air quality standard is $40 \mu \mathrm{g} / \mathrm{m}^{3}$. As a result of this study, taxis were banned from entering the station from 2 June 2014 and now have to park in the open air outside.

\subsection{New Street station, Birmingham (35 million passenger entries/exits)}

Birmingham's New Street station has undergone an extensive $£ 600 \mathrm{~m}$ revamp, which was completed in September 2015 (Thornes, 2015), but platform improvements are still ongoing. It is envisaged that passenger numbers at the 'new' New Street station may treble in the near future. Up to 140000 people/d currently use the station and the annual numbers of passengers has increased by $8 \%$ in the last year to 35 million passengers despite the redevelopment. The unique underground nature of the platforms at this station has changed little (Figure 1). The enclosed space is approximately $5 \mathrm{~m}$ high, $160 \mathrm{~m}$ wide and about $240 \mathrm{~m}$ long, giving a volume less than half that of the enclosed space at Paddington. An unpublished survey of air quality at the station was carried out before construction work began (Personal communication, Birmingham City Council, 2014), which stated

The results provide a benchmark to which potential monitoring results may be compared. Network Rail is particularly concerned over the potential health effects of pollutant emissions from diesel engines on construction workers and station staff.

It is interesting that passenger health was not mentioned. A 3-month monitoring period during the summer and autumn of 2009 was used to look at the diesel exhaust pollutants: oxides of nitrogen, particulate matter $\left(\mathrm{PM}_{10}\right)$, carbon dioxide, sulfur dioxide and PAHs. The report concluded that the only pollutants that should be measured during construction of the new station should be $\mathrm{PM}_{10}$ and carbon dioxide and not nitrogen dioxide, despite the findings that

\footnotetext{
...the nitrogen dioxide concentrations exceed the statutory annual mean air quality objective of $40 \mu \mathrm{g} / \mathrm{m}^{3}$ at all locations... It is likely that the short-term hourly objective of $200 \mu \mathrm{g} / \mathrm{m}^{3}$ was periodically exceeded on several occasions on all platforms and the concourse.
}

These diffusion tube measurements (Table 3) do not take into account the fact that the station has virtually no trains for a quarter of the day, between midnight and 6 a.m. Furthermore, the diffusion tubes were placed at the entrance to the platform 'tunnels' rather than in the centre of the tunnels where the pollution levels are likely to be highest.

Obviously, diesel fumes affect passengers (public health) as well as staff (occupational health). However, some staff 


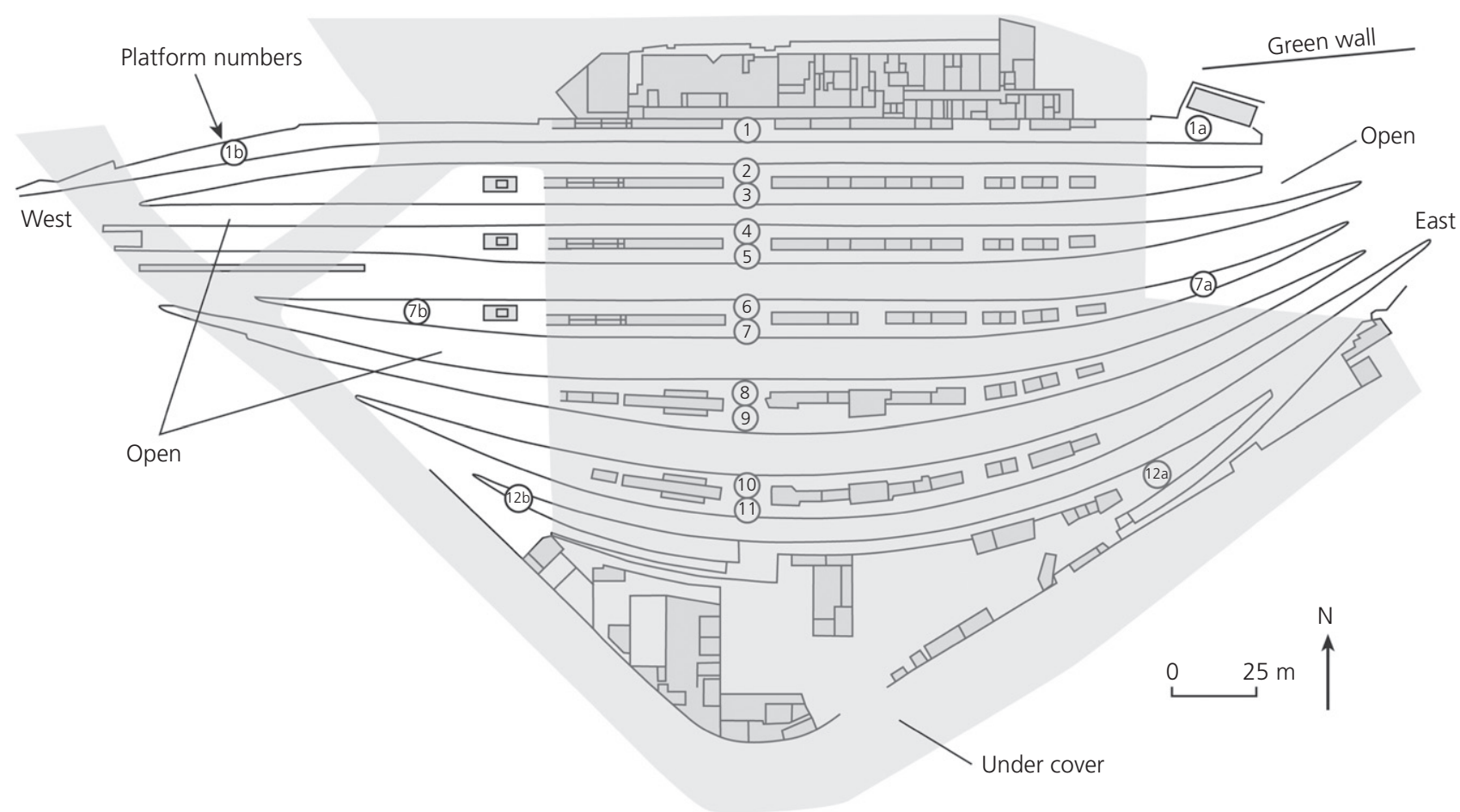

Figure 1. Plan view of New Street station, Birmingham, UK

\section{Location} Nitrogen dioxide concentration: $\mu \mathrm{g} / \mathrm{m}^{3}$

\section{Concourse}

Platform 2

$142 \cdot 1$

Platform 4

$303 \cdot 1$

Platform 6

$192 \cdot 8$

$185 \cdot 1$

Platform 8

$235 \cdot 4$

Platform 10

$218 \cdot 3$

Platform 12

Table 3. Concentrations recorded over 3 months by diffusion tubes for nitrogen dioxide at New Street station in 2009 pre-revamp (annual air quality threshold is $40 \mu \mathrm{g} / \mathrm{m}^{3}$ )

members are on duty for several hours whereas most passengers pass through the station within half an hour - although this can be much longer when there are delays. The Confidential Incident Reporting \& Analysis System (Ciras) is a confidential reporting system for the health and safety concerns of employees. There have been two similar complaints (Ciras, 2013a, 2013b) about air quality at the station, with one member of staff (Ciras, 2013a: p. 1)

...concerned that the build-up of diesel fumes at Birmingham New Street is affecting the health of the staff who work there. Station workers are complaining about headaches and spells of dizziness.

The responses from the train operating companies and Network Rail were as follows (Ciras, 2013a: p. 3).

\begin{abstract}
Our national diesel engine shutdown policy requires that trains that are going to be standing for more than 15 min to be shut down upon arrival and restarted 10 min before departure.
\end{abstract}

...we shut down engines on trains that are to be detained at New Street more than 20 min.

The new ventilation system is an impulse fan system; on completion, the new system will consist of over 90 fans which will be visible from the platforms. To monitor the effectiveness of the ventilation the project measures carbon dioxide levels at platform level. Anyone experiencing adverse feelings while working on the station should report it immediately to their supervisor.

This shows a primary concern with carbon dioxide and does not recognise that headaches and dizziness can be caused by other pollutants such as nitrogen dioxide.

The decision to monitor carbon dioxide levels is based on HSE guidance on diesel emissions in the workplace (HSE, 2012), which advises that DEEEs are not subject to Coshh (Control of Substances Hazardous to Health) regulations (HMG, 2002b) concerning the control of carcinogenic substances. However, as already discussed, recent research has 
classified DEEEs as carcinogenic and the HSE needs to update its WELs. The HSE recommends that carbon dioxide is monitored as a general guide to ventilation and pollution levels. This recommendation needs to be urgently updated to include DEEEs and demand that other air pollutants also be monitored.

As Birmingham New Street is an enclosed station, measures have recently been taken to reduce pollutants around the platforms through the installation of fans. This impulse fan system responds to the levels of carbon dioxide in the station: the fans begin to operate once carbon dioxide exceeds $1000 \mathrm{ppm}$ and the speed of the fans increases relative to pollution levels. However, the fans only respond to carbon dioxide levels and therefore harmful levels of other pollutants such as nitrogen dioxide and particulate matter may go unnoticed, with the health of employees and passengers possibly being affected. Information gathering during the monitoring process at Birmingham New Street is ongoing but it is hoped that with the use of the fans, pollution levels do not exceed the workplace limits.

Conversely, a recent survey conducted in April 2015 measured the levels of $\mathrm{PM}_{2.5}$ and black carbon (BC) - a tracer of diesel emissions - during $1 \mathrm{~h}$ intervals at New Street station using real-time sensors. The concentrations reported were up to $58 \mu \mathrm{g} / \mathrm{m}^{3}$ for $\mathrm{PM}_{2.5}$ and up to $29 \mu \mathrm{g} / \mathrm{m}^{3}$ for BC (Zulkifli, 2015). The highest concentrations measured at the platform level were associated with idling trains, with increases up to six times higher than concentrations measured with passing trains. This suggests that idling trains are the main source of exposure to high levels of air pollutants in railway stations.

\section{Conclusions}

The main finding of this review is that air quality at the enclosed railway stations considered does not meet European air quality standards for nitrogen dioxide and particulate pollution. Currently, occupational health standards are used to determine air quality. This is probably not a problem for wellventilated outdoor railway stations. However, for enclosed railway stations, which are effectively 'indoors', public health guidelines could be used and it is likely that the air quality measured by the daily air quality index (MO, 2016) in enclosed railway stations could be classed as 'very high' on a daily basis. To confirm this, air pollution levels and public health effects for commuters using enclosed railway stations need to be monitored and compared with other forms of commuter transport into cities.

Recommendations for interventions to improve air quality at enclosed railway stations include

- reducing the number of diesel trains

- improving the quality of the diesel fuel used
- using more up-to-date diesel trains with more efficient engines

- fitting efficient diesel particle traps

- reducing idling times at station platforms

- increasing the amount of ventilation linked to nitrogen dioxide and/or particulate levels as well as carbon dioxide levels.

Ultrafine particulates from electric trains should also be monitored and platforms and railtrack beds should be regularly cleaned to remove particulates and prevent recirculation.

It is clear that a combination of public air quality standards and occupational air quality standards needs to be developed and applied in enclosed railway stations.

\section{REFERENCES}

Abbasi S, Jansson A, Sellgren U and Olofsson U (2013) Particle emissions from rail traffic: a literature review. Critical Reviews in Environmental Science and Technology 43(23): 2511-2544.

AEA Technology (2001) Rail Emission Model. A Report for the Strategic Rail Authority. AEA Technology, Harwell, UK. AQEG (Air Quality Expert Group) (2004) Nitrogen Dioxide in the United Kingdom. AQEG, London, UK. See http://uk-air. defra.gov.uk/assets/documents/reports/aqeg/nd-summary. pdf (accessed 02/09/2015).

Carslaw D, Beevers S, Westmoreland E et al. (2011) Trends in $\mathrm{NOx}$ and $\mathrm{NO}_{2}$ Emissions and Ambient Measurements in the UK. Defra, London, UK. See http://uk-air.defra.gov. uk/assets/documents/reports/cat05/1108251149_110718_ AQ0724_Final_report.pdf (accessed 02/09/2015).

Chong U, Swanson JJ and Boies AM (2015) Air quality evaluation of London Paddington Train Station. Environmental Research Letters 10(9): 1-11.

Ciras (Confidential Incident Reporting \& Analysis System) (2013a) 51127 Diesel Fumes at Birmingham New Street. Ciras, London, UK. See http://www.ciras.org.uk/reportlibrary/train-operations/51127-diesel-fumes-at-birminghamnew-street/ (accessed 14/10/2015).

Ciras (2013b) 52136 Air Quality During Station Work at New Street Station. Ciras, London, UK. See http://www.ciras. org.uk/report-library/network-rail-and-suppliers/52136-airquality-during-station-work-at-birmingham-new-street/ (accessed 14/10/2015).

COMEAP (Committee on the Medical Effects of Air Pollutants) (2010) The Mortality Effects of Long-Term Exposure to Particulate Air Pollution in the United Kingdom. Public Health England, London, UK.

Defra (Department for Environment, Food and Rural Affairs) (2011) Air Quality Plan for the Achievement of EU Air Quality Limit Values for Nitrogen Dioxide $\left(\mathrm{NO}_{2}\right)$ in West Midlands Urban Area (UK0002). Defra, London, UK. 
Defra (2013) Effects of Air Pollution. Defra, London, UK. See http://uk-air.defra.gov.uk/air-pollution/effects (accessed 04/09/2015).

Defra (2014) Updated Projections for Nitrogen Dioxide ( $\left.\mathrm{NO}_{2}\right)$ Compliance. Defra, London, UK. See http://uk-air.defra. gov.uk/assets/documents/no2ten/140708_N02_projection_ tables_FINAL.pdf (accessed 03/09/2015).

Defra (2015) Air Quality Plan for the Achievement of EU Air Quality Limit Value for Nitrogen Dioxide $\left(\mathrm{NO}_{2}\right)$ in West Midlands Urban Area (UK0002). Defra, London, UK.

DoT (Department of Transport) (2009) Britain's Transport Infrastructure: Rail Electrification. DoT, London, UK.

Durmusoglu E, Taspinar F and Karademir A (2010) Health risk assessment of BTEX emissions in the landfill environment. Journal of Hazardous Materials 176(1-3): 870-877.

EC (European Commission) (2012a) Air Quality - Existing Legislation. EC, Brussels, Belgium. See http://ec.europa.eu/ environment/air/quality/legislation/existing_leg.htm (accessed 03/09/2015).

EC (2012b) Air Quality Standards. EC, Brussels, Belgium. See http://ec.europa.eu/environment/air/quality/standards.htm (accessed 04/09/2015).

EC (2014) Environment: Commission Takes Action Against UK for Persistent Air Pollution Problems. EC, Brussels, Belgium. See http://europa.eu/rapid/press-release_IP-14154_en.htm (accessed 03/09/2015).

EC (European Community) (1999) Council Directive 1999/30/EC of 22 April 1999 relating to limit values for sulphur dioxide, nitrogen dioxide and oxides of nitrogen, particulate matter and lead in ambient air. Official Journal of European Communities L163/1.

EC (2008) Directive 2008/50/EC of the European Parliament and of the Council of 21 May 2008 on ambient air quality and cleaner air for Europe. Official Journal of the European Union L152/1.

EC (2009) Regulation (EC) No 595/2009 of the European Parliament and of the Council of 18 June 2009 on typeapproval of motor vehicles and engines with respect to emissions from heavy duty vehicles (Euro VI) and on access to vehicle repair and maintenance information and amending Regulation (EC) No 715/2007 and Directive 2007/46/EC and repealing Directives 80/1269/EEC, 2005/ 55/EC and 2005/78/EC. Official Journal of the European Union L188/1.

Environment Act 1995 (1995) Elizabeth II. Chapter 25. Her Majesty's Stationery Office, London, UK.

Gardner B (2012) Environmental Air Quality Monitoring Assessment: Waverley Station, Edinburgh. FES Ltd, Stirling, UK.

Greener Business (2008) Birmingham is the Worst City for Commuting. Greener Business, Manchester, UK. See http:// www.greenerbusiness.co.uk/news/birmingham-worstcitycommuting-2008141 (accessed 15/09/2015).
Harper P (2011) Assessment of the Major Hazard Potential of Carbon Dioxide ( $\mathrm{CO} 2$ ). HSE, London, UK. See http://www.hse.gov.uk/carboncapture/assets/docs/ major-hazard-potential-carbon-dioxide.pdf (accessed 04/09/2015).

HCEAC (House of Commons Environmental Audit Committee) (2014) Action on Air Quality. HCEAC, London, UK. See http://www.publications.parliament.uk/pa/ $\mathrm{cm} 201415 / \mathrm{cmselect} / \mathrm{cmenvaud} / 212 / 21202 . \mathrm{htm}$ (accessed 14/10/2015).

Hertel O and Goodsite ME (2009) Urban air pollution climates throughout the world. In Air Quality in Urban Environments. Issues in Environmental Science and Technology, vol. 28 (Hester RE and Harrison RM (eds)). RSC Publishing, Cambridge, UK, pp. 1-22.

HMG (Her Majesty's Government) (2000) Environmental Protection, England. The Air Quality (England) Regulations 2000. The Stationery Office, London, UK, Statutory Instrument 2000 No. 928.

HMG (2002a) Environmental Protection, England. Air Quality (England) (Amendment) Regulations 2002. The Stationery Office, London, UK, Statutory Instrument 2002 No. 3043.

HMG (2002b) Health and Safety. Control of Substances Hazardous to Health Regulations 2002. The Stationery Office, London, UK, Statutory Instrument 2002 No. 2677.

HMG (2010) Environmental Protection. The Air Quality Standards Regulations 2010. The Stationery Office, London, UK, Statutory Instrument 2010 No. 1001.

Hope C (2015) Labour made 'wrong decision' over diesel car tax, admits shadow minister. The Telegraph, 25 January. See http://www.telegraph.co.uk/news/politics/11368568/ Labour-made-wrong-decision-over-diesel-car-tax-admitsshadow-minister.html (accessed 03/09/2015).

HSE (Health and Safety Executive) (2012) Control of Diesel Engine Exhaust Emissions in the Workplace. HSE, London, UK, pp. 1-22.

HSE (2013) EH40/2005 Workplace Exposure Limits: Containing the List of Workplace Exposure Limits for Use with the Control of Substances Hazardous to Health Regulations 2002 (as Amended). HSE, London, UK.

IARC (International Agency for Research on Cancer) (2012) IARC: Diesel Engine Exhaust Carcinogenic. IARC, Lyon, France. See http://www.iarc.fr/en/media-centre/pr/2012/ pdfs/pr213_E.pdf (accessed 04/10/2015).

Kim KH, Jahan SA, Kabir E et al. (2013) A review of airborne polycyclic aromatic hydrocarbons (PAHs) and their human health effects. Environment International 60(1): 71-80.

Loxham M, Copper MJ, Gerlofs-Nijland ME et al. (2013) Physicochemical characterization of airborne particulate matter at a mainline underground railway station. Environmental Science and Technology 47(8): 3614-3622. 
Martins V, Moreno T, Mendes L et al. (2016) Factors controlling air quality in different European subway systems. Environmental Research 146(1): 35-46.

Mills IC, Atkinson RW, Kang S et al. (2015) Quantitative systematic review of the associations between short-term exposure to nitrogen dioxide and mortality and hospital admissions. BMJ Open 5(5): 1-8.

MO (Met Office) (2016) Daily Air Quality Index. MO, Exeter, UK. See http://www.metoffice.gov.uk/guide/ weather/air-quality (accessed 22/03/2016).

NR (Network Rail) (2015) Electrification. NR, London, UK. See http://www.networkrail.co.uk/aspx/12273.aspx (16/09/2015).

ORR (Office of Rail and Road) (2015) Passenger Journeys by Year. ORR, London, UK. See http://dataportal.orr. gov.uk/displayreport/report/html/02136399-b0c5-4d91a85e-c01f8a48e07e (accessed 15/09/2015).

RDG (Rail Delivery Group) (2015) GB Rail: Better Services, Better Journeys and Better Value. RDG, London, UK. See http://www.raildeliverygroup.com/what-we-do/publications. html?task=file. download\&id=649 (accessed 15/09/2015).

Rincon P (2015) Court Orders UK to Cut $\mathrm{NO}_{2}$ Air Pollution. BBC, London, UK. See http://www.bbc.co.uk/news/scienceenvironment-32512152 (accessed 03/09/2015).

RSSB (Railways Safety and Standards Board) (2014) Rail Industry Eyes $£ 32 \mathrm{~m}$ Yearly Saving by Improving Health and Wellbeing. RSSB, London, UK. See http://www.rssb. co.uk/Library/about-rssb/2014-04-28-press-release-railindustry-eyes-32m-yearly-saving-by-improving-health-andwellbeing.pdf (accessed 15/09/2015).
Salma I (2009) Air pollution in underground railway systems. In Air Quality in Urban Environments. Issues in Environmental Science and Technology, vol. 28 (Hester RE and Harrison RM (eds)). RSC Publishing, Cambridge, UK, pp. 65-84.

Swinford S (2015) Diesel car drivers paying $£ 3$ more than they should to fill tanks. The Telegraph, 17 April. See http:// www.telegraph.co.uk/news/earth/energy/fuel/11542845/ Diesel-car-drivers-paying-3-more-than-they-should-to-filltanks.html (accessed 03/09/2015).

Thornes TJW (2015) Variations of temperature, wind speed and humidity within Birmingham New Street Station during hot weather. Weather 70(4): 129-134.

Vidal J (2014) Diesel engine pollution linked to early deaths and costs NHS billions. The Guardian, 29 April. See http:// www.theguardian.com/environment/2014/apr/29/dieselengine-pollutionpremature-deaths-costs-nhs-billions (accessed 10/05/2016).

WHO (World Health Organization) (2013) Review of Evidence on Health Aspects of Air Pollution - REVIHARP Project Technical Report. WHO, Geneva, Switzerland. See http://www.euro.who.int/_data/assets/pdf_file/0004/193108/ REVIHAAP-Final-technical-report-final-version.pdf ?ua=1 (accessed 15/09/2015).

WHO (2015) Ambient (Outdoor) Air Quality and Health. WHO, Geneva, Switzerland. See http://www.who.int/ mediacentre/factsheets/fs313/en/ (accessed 04/09/2015).

Zulkifli MN (2015) The Effect of Train Station Design towards Commuters' Exposure. MSc dissertation, University of Birmingham, Birmingham, UK.

\section{HOW CAN YOU CONTRIBUTE?}

To discuss this paper, please email up to 500 words to the editor at journals@ice.org.uk. Your contribution will be forwarded to the author(s) for a reply and, if considered appropriate by the editorial board, it will be published as discussion in a future issue of the journal.

Proceedings journals rely entirely on contributions from the civil engineering profession (and allied disciplines). Information about how to submit your paper online is available at www.icevirtuallibrary.com/page/authors, where you will also find detailed author guidelines. 